\title{
ПРЕЖДЕВРЕМЕННАЯ ЭПИТАФИЯ АМЕРИКАНСКОЙ ГЕГЕМОНИИ
}

Nye. Is the American Century over? John Wiley and Sons, 2๑15. $152 \mathrm{p}$.

Най Дж. Закончился ли американский век? Изд-во Джон Уайли энд Санз, 2015. 152 с.

Закончился ли американский век? Вопрос этот поднимался не раз - под влиянием различных событий он периодически вновь и вновь становится предметом ожесточенных обсуждений американской и мировой общественности. Согласно опросам исследовательской службы Pew Poll, в 2014 г. на вопрос, считают ли они свою страну превосходящей все остальные, только $28 \%$ американских обывателей ответили утвердительно, что на $10 \%$ меньше показателей, зафиксированных тремя годами ранее. Схожая тенденция заметна и за пределами США - в 15 из 22 стран, участвовавших в опросе, респонденты предвещают первенство в мировой экономике, а следом - и в политике Китаю.

Джозеф Най-младший, заслуженный профессор Гарвардского университета, более оптимистичен в своих оценках перспектив американского лидерства. В своей новой книге (которая так и называется «Закончился ли американский век?») он дает оценку современной роли США на международной арене и предлагает прогноз ее будущей эволюции. Книга примечательна не только глубоким анализом внутренней и внешней политики США. Най проводит комплексное осмысление сложившейся после краха биполярности международной системы. При этом он предостерегает от поспешных выводов и скоропалительных умозаключений относительно даль- нейшей судьбы США и всего мирового порядка в упрощенных категориях упадка или подъема американской мощи. При всей важности экономического, военного и ценностного влияния решающую роль, по мнению профессора Ная, будет играть способность найти новые подходы к решению глобальных проблем, с которыми ни одно, даже самое могущественное государство, не способно справиться в одиночку.

Для начала автор предлагает очертить временные рамки «американского века». Если брать за основу критерий экономической мощи, то «американским» можно считать XX век. Пика экономического могущества США достигли после Второй мировой войны. Най, однако, сразу делает существенную оговорку о необходимости включения в анализ «триады потенциала» государства. Последняя включает в себя, помимо экономики, военную силу и «мягкую мощь». С позиций подобного комплексного анализа можно было бы предположить, что американский век начался с отправки американских войск в Европу в 1917 году. Но Най все же предлагает вести отчет с решения Франклина Рузвельта вступить во Вторую мировую войну, поскольку между этими двумя событиями имел место период изоляционизма во внешней политике США.

Наконец, третьей возможной датой начала «американского века» называется 1991 год, когда после распада Советского Союза США

Статья подготовлена в рамках реализации гранта Российского гуманитарного научного фонда № 15-03-00728. 
стали единственной державой, способной проецировать военную мощь на глобальном уровне. При этом автор предлагает отказаться от термина «гегемон», поскольку не ясно, включает ли в себя эта концепция преимущество в ресурсах, способность устанавливать правила для других участников международных отношений, либо же она подразумевает возможность получения желаемых результатов любыми путями. Неоднозначность трактовки понятия «гегемония» затрудняет определение временных рамок ее существования. В этой связи для обозначения несоразмерно большой доли одного государства в обладании всеми тремя властными ресурсами Най предлагает использовать категории «первенства» (primacy) и «превосходства» (preponderance).

Истоки заката американской эпохи могут лежать в двух плоскостях - это либо подъем других государств, что неминуемо приведет к ослаблению относительной мощи США, либо упадок самой страны, стагнация и кризис в экономической и социальной сферах. Рассматривая эволюцию ресурсного потенциала других стран, Най называет несколько претендентов на «смещение» Америки с пьедестала, давая при этом обширный и аргументированный обзор всех трех составляющих «умной силы» - экономики, военной мощи и культурной и ценностной привлекательности.

Европейский Союз в экономическом плане сравним с США (европейский рынок является крупнейшим и составляет $17 \%$ мировой торговли, на 5\% опережая американский). В таких влиятельных экономических структурах, как ВТО и МВФ, он играет либо главную роль, либо встает вровень с США. Тем не менее стареющее население и нарастающий приток мигрантов оказываются для Старого света серьезной проблемой. Демографический кризис порождает множество сложностей в экономике и ставит под удар европейские ценности: из раза в раз европейцы демонстрируют, что национальная идентичность для них важнее общеевропейской. Европейские ценности попрежнему остаются притягательными для большого количества людей со всего мира, вместе с тем по показателям «мягкой мощи» Европа явно проигрывает - расходы на фундаментальные исследования ниже, чем в США, а из 100 лучших университетов только 27 находятся в Старом свете (в Соединенных Штатах - 52). Однако главная причина, по которой Вашингтону не стоит бояться ЕС, - два глобальных игрока остаются союзниками, у них тесные экономические связи и общие либерально-демократические и гуманитарные ценности.

Аналогичные доводы Най приводит и в отношении Японии. После галопирующего экономического роста, когда Токио предрекали роль как минимум тихоокеанского лидера, последовал двадцатилетний период «нулевого» экономического развития. Хотя Япония обладает рядом преимуществ: высокотехнологичное производство, современная армия, высокий уровень социальной стабильности и квалифицированная рабочая сила - она также испытывает демографические трудности, ее мягкая мощь ограничена традиционными культурными и политическими особенностями, а территориальные споры в Восточно-Китайском море делают маловероятным союз с Китаем, вместе с которым Япония могла бы составить конкуренцию США. Най отмечает важность союзничества ЕС и Японии с Соединенными Штатами: оно не только открывает новые возможности в решении глобальных проблем, с которыми одной сверхдержаве не справиться, но и взаимно усиливает позиции этих участников на международной арене.

Россия, по мнению Ная, также не может в данный момент составить конкуренцию США, что в первую очередь обусловлено внутренними причинами - экономикоуправленческими (неэффективное распределение ресурсов в экономике и высокая степень зависимости от экспорта энергоносителей), политическими и социально-демографическими. Союзу с Китаем, несмотря на риторику «стратегического партнерства», «дружбы и сотрудничества» мешает конкуренция за Центрально-Азиатский регион и соперничество на Дальнем Востоке.

Индия имеет бесспорное преимущество в виде огромного населения, численность ко- 
торого в четыре раза больше американского, обладает внушительной военной мощью, многочисленным средним классом, а статус английского языка как официального расширяет ее возможности в информационной сфере. Кроме того, Индия обладает мягкой силой в лице многочисленной диаспоры по всему миру и привлекательной культуры (Болливуд является мировым лидером по числу выпускаемых фильмов). Но при этом грамотность индийского населения не превышает 63\%, а в условиях крайней нищеты живут 1,1 миллиард человек. Индия могла бы составить конкуренцию США только в союзе с Китаем, но, несмотря на растущий объем торговли между двумя странами, в политической сфере их отношения остаются напряженными, и периодически вспыхивающие пограничные конфликты делают такой союз маловероятным.

Крупнейшая страна в Латинской Америке Бразилия, несмотря на успехи в экономике и свою культурную привлекательность, испытывает серьезные социальные трудности, коррупция и уровень преступности слишком высоки, а успехи во внешней политике пока не столь впечатляющи, чтобы позволить стране составить конкуренцию США.

Таким образом, единственным государством, потенциально способным бросить вызов Соединенным Штатам, становится Китай, которому Най посвящает отдельную главу. Согласно прогнозам, китайская экономика в обозримой перспективе станет крупнейшей не только по ППС, но и по обменным курсам. Вместе с тем даже при равных объемах структура американской и китайской экономик едва сопоставимы. КНР еще только предстоит справиться с огромными разрывами в уровнях развития регионов (обширные неразвитые сельские районы на юге и востоке страны), а также решить демографические проблемы, вызванные проводимой ранее политикой «одна семья - один ребенок». Бурный экономический рост и растущие доходы населения ставят вопрос о необходимости расширения политического участия при сохранении монополии на власть за КПК. Пока у китайского руководства нет вариантов ответа на эти вопросы. Претерпит ли авторитарная модель управления изменение после достижения подушевого ВВП отметки в 10000 долларов (как это произошло в Южной Корее и Тайване), остается большой загадкой и для китайского руководства, и для всего мира. Растущий военный бюджет Китая также выглядит не столь внушительно при сравнении его с аналогичными показателями США (11\% и $37 \%$ от общемировых трат на вооружения соответственно). Главный инструмент и проводник «мягкой мощи» в КНР - государство (в отличие от США, где она исходит почти всецело от гражданского общества), и это, по мнению Ная, превращает ее в пропаганду и делает намного менее эффективной.

Най отмечает, что в отношении Китая и всего азиатского региона политика США должна состоять в поддержании баланса сил и стимулировании региональной интеграции открытого типа - включающей Японию, США, Австралию, Индию. Развитие союзнических отношений с Японией и Индией позволит сдерживать Китай, а вовлечение Китая в систему международных институтов смотивирует его к более ответственному поведению и снизит вероятность проявления агрессии в период активного экономического роста.

Политолог приходит к выводу, что у США нет конкурентов, которые могли бы претендовать на мировое господство. Между тем существуют вызовы внутри страны, которые могут привести к ее упадку. И хотя Най отрицает версию об «имперском перенапряжении» Соединенных Штатов (расходы на оборону и внешнюю политику не только не выросли, но, напротив, сократились в процентном соотношении к ВВП), он указывает на проблемы, способные в перспективе ослабить мощь США. Это и возрастающий объем государственного долга, и проблемы в сфере образования, и кризис политической системы. Снижение уровня доверия к государственным институтам происходит вследствие принципов, на которых основаны Соединенные Штаты: Конституция страны была разработана таким образом, чтобы 
препятствовать централизации власти и всячески уравновешивать различные политические силы путем сдержек и противовесов. Иммиграция, хоть и оказывается источником социальных проблем, в долгосрочной перспективе способствует росту мощи США, позволяя избежать демографических проблем и увеличивая «мягкую мощь». Ограничение иммиграции и закрытие границ из-за опасности терроризма, напротив, видится Наю нежелательным сценарием, при котором Америка потеряет свои конкурентные преимущества перед другими странами.

В подтверждение тезиса о внутреннем упадке Соединенных Штатов многие аналитики оперируют сравнением положения в стране с опытом Британской Империи в период ее заката, но Най оспаривает этот тезис, приводя в качестве аргументов более выгодное геополитическое положение (два океана и слабые соседи, в то время как рядом с Великобританией находились набирающие силу Россия и Германия), а также экономические и военные трудности, которые к началу XX века уже назрели в империи (Великобритания занимала лишь четвертое место по объему ВВП и численности вооруженных сил, и третье место по объему военных расходов). Кроме того, не стоит забывать, что основой влияния Британской империи были колонии, а фундамент международного влияния США - альянсы.

Идея естественного упадка также отвергается Наем, государство не человек, и не имеет предсказуемой продолжительности жизни. Рим являлся господствующей империей еще три столетия после достижения им пика своего могущества, и крушение Римской империи произошло отнюдь не по причине возвышения другого государства.

Отсюда главный вызов для США в XXI веке - выбор стратегии поведения в меняющемся мире. Упадок гегемона традиционно объясняется «силовым транзитом», но такое объяснение Най считает некорректным. Сегодня имеет место не переход мощи от одного государства к другому, а ее распыление, диффузия между всеми участниками международных отношений, в том числе негосударственными. США не пере- живают внутреннего упадка, который мог бы подорвать их лидерство. Что касается относительного могущества, то вряд ли какое-либо государство сможет в ближайшие десятилетия оказаться сильнее Соединенных Штатов. Вместе с тем глобализация и усложняющаяся международная среда ставят новые задачи, и даже самое могущественное государство не способно будет справиться в одиночку со всеми вызовами. Поэтому перед Вашингтоном стоит задача разумного сочетания жесткой и мягкой силы, дальнейшего укрепления и расширения союзов с целью объединения ресурсов.

Монография «Закончился ли американский век?» не только дает возможность оценить тенденции трансформации международной среды, но также полезна в контексте изучения американской внешнеполитической мысли. Джозеф Най отрицает наступление «постамериканского мира», США останутся глобальным игроком на мировой арене, но для этого потребуется качественно новый подход и политика, отвечающая новым реалиям. Только разумное сочетание жесткой и мягкой силы, сотрудничество с другими участниками международных отношений и создание обширных объединений позволят США сохранить лидерство и справиться с существующими проблемами. На первый план выходят уже не военный или экономический потенциал, а концептуальное и идеологическое оформление стратегии государства, его способность ставить правильные долгосрочные цели и достигать их.

Лидерство и доминирование - это не одно и то же, и проведенный Наем анализ американской истории доказывает, что не всегда обладание ресурсами гарантирует достижения желаемых целей. Сегодня отрыв США от других участников международной системы несколько меньше, а комплексность глобальной среды значительно выше, но если США смогут разработать «умную» стратегию, то сохранят лидирующие позиции, и «американский век» продлится еще не одно десятилетие. Правда, выглядеть он будет уже иначе, чем прежде.

Ляна Дымова 